\title{
Study of water curtain effectiveness to fight against vapours of methyl acetate during uncontrolled release
}

\author{
Tomasz Węsierski ${ }^{1,{ }^{*}}$, Matgorzata Majder-Łopatka ${ }^{1}$ and Wiktor Wąsik ${ }^{1}$ \\ ${ }^{1}$ The Main School of Fire Service, Faculty of Fire Safety Engineering, 52/54 Slowackiego St., 01-629 \\ Warsaw, Poland
}

\begin{abstract}
The paper presents results of studies concerning the effectiveness of water curtains in eliminating airborne vapours of methyl acetate. It was found that for methyl acetate the determined effectiveness of water curtains was 13.57 times lower than that of ammonia. In practical terms the absorption rate of methyl acetate vapours equalled to the absorption rate set out for ethanol, but was much lower than for methanol. The obtained results have pointed to the efficiency of water curtains in incidents that comprise uncontrolled release of methyl acetate.
\end{abstract}

\section{Introduction}

Rescue actions implemented in the event of uncontrolled releases of hazardous substances depend on a considerable variety of hazards that may occur on the site of incident [1-10]. To be able to assure the appropriate efficiency of measures, in the majority of cases the adopted technologies must nevertheless assume the use of cheap and easily accessible materials, such as for example water. One of the technologies that enable effective use of water assumes the application of water curtains, which may be used in the spatial elimination of vapours, steam, dusts, electrostatic charges, limiting the endangered space, diluting, and protecting facilities from thermal radiation. Their effectiveness is a function of numerous variables that depend on the location where the action is being implemented, weather conditions and objective of using the curtain. As regards spatial elimination of chemical hazards, their efficacy on vapours of hazardous substances depends among others on the solubility of the given substance in water, reactivity to it or towards ingredients contained by it, as well as the rate of diffusion to the inside of the droplet. [11]. This is reflected in experimental data, because substantial suitability of water has been ascertained in the elimination process of such compounds as ammonia, hydrogen fluoride, acetone, low molecular aliphatic alcohols, which become very well dissolved in water [11-21]. For chlorine, the solubility of which is $7 \mathrm{~g} / \mathrm{dm}^{3}$ of water $\left(20^{\circ} \mathrm{C}\right)$, the ascertained efficacy was insignificant or even negligible [22]. In addition extensive studies were performed of the possibilities of applying water curtains to eliminate hazards related to vapours of hydrocarbons and hydrocarbon mixtures [23-26]. Given the very low solubility

\footnotetext{
*Corresponding author: twesierski@sgsp.edu.pl
} 
of hydrocarbons in water, no significant reduction in vapour concentration is recorded. On the other hand, as regards substances with limited solubility in water, it is all the same possible to use water curtains as barriers to shifting of hydrocarbon vapour clouds or in the case of appropriate intensity and direction of spraying as an element that facilitates dispersion [27]. The dilution effect would depend among others on the intensity of water jet spraying, the distance between the nozzle and the point of release, and the type of nozzle [27]. This paper presents research conducted for methyl acetate, which leads to a fire and explosion hazard in the event of uncontrolled release. A relatively good solubility in water $\left(319 \mathrm{~g} / \mathrm{dm}^{3}, 20^{\circ} \mathrm{C}\right)$ allows the presumption of high effectiveness of water curtains in the elimination process of vapours of this compound found in the air.

\section{Experimental part}

\subsection{Materials}

Use was made of analytically pure methyl acetate with a purity of min. $99.5 \%$ produced by Avantor Performance Materials (formerly POCh Gliwice).

\subsection{Testing methodology}

During the research analyses were made related to a change in the concentration of methyl acetate in the function of time following the subjecting of its vapours to overhead water curtain. The water jet was sprayed from a nozzle with a diameter of $1 \mathrm{~mm}$. It was found that for the analysed output range of water curtains this jet was characterised by a droplet diameter from $270 \mu \mathrm{m}<\mathrm{d}<247 \mu \mathrm{m}$ which by definition categorises it to fog jet ( $\mathrm{d}<1 \mathrm{~mm}$ ). Droplets of that size were found to have a large sorption area as well as an acceptable resistance to windy weather. The characteristic features of the water jet droplet distribution used in our research were presented in figure $1 \mathrm{~A}$.

To study average droplet diameters used was made of the AWK Drop Spectrum Analyzer made by Zakład Elektronicznej Aparatury Pomiarowej $\mathrm{K} \mu \mathrm{K}$ in Warsaw. The analyzer allows the determination of average droplets diameter in the range from $0.5 \leq \mathrm{d} \leq$ $3000 \mu \mathrm{m}$. A diagram of the device has been presented in figure 1B.

The tests were carried out in a tight measurement chamber having a volume of $322.4 \mathrm{dm}^{3}(476 \times 676 \times 1002 \mathrm{~mm})$ as presented on figure 2 . The fog stream came from a single nozzle provided at the centre of the upper chamber wall. The research atmosphere was generated by unconstrained vaporisation of methyl acetate samples from Petri dishes having a diameter of $9 \mathrm{~cm}$ which was meant to simulate conditions of uncontrolled release of acetone within a limited storage facility. To achieve a representative number of research trials characterised by different initial concentration of acetone in the chamber the evaporation time of samples was varied. 
A

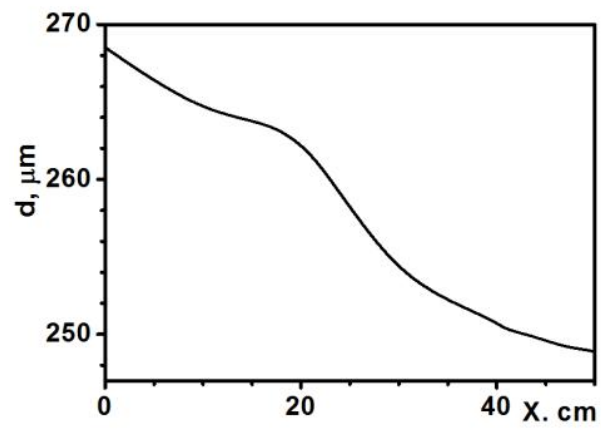

B

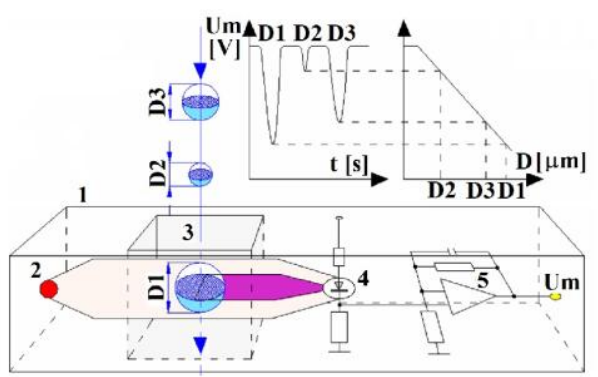

Fig. 1. (A) Characteristics of droplet distribution of water stream used in tests. Nozzle with a diameter of $\Phi=1 \mathrm{~mm} ; \mathrm{d}$ - average droplet diameter; X - distance from the curtain centreline. (B) AWK Drops Spectrum Analyzer scheme: 1 - probe, 2 - transmitter, 3 - measuring space, 4 - receiver, 5 electronical arrangement, D1, D2, and D3 - adequate size of droplets.

Testing the efficacy of water curtains in relation to methyl acetate was performed at an intensity of $90 \mathrm{dm}^{3} / \mathrm{h}$. The concentration was measured using a multi-sensor device IBRID MX6, which allows making measurements both in the mode of a photoionisation detector (PID) as well as a catalytic combustion sensor (explosimeter). Measurement within the range up to $2000 \mathrm{ppm}$ may be carried out with the use of PID. Bigger concentrations were determined with the use of the explosimeter and converted into ppm according to the value of calibration coefficients attached in documentation of the device. 1\% LEL on the explosimeter scale calibrated to pentane meant $135 \mathrm{ppm}$ on the PID scale set at methyl acetate.

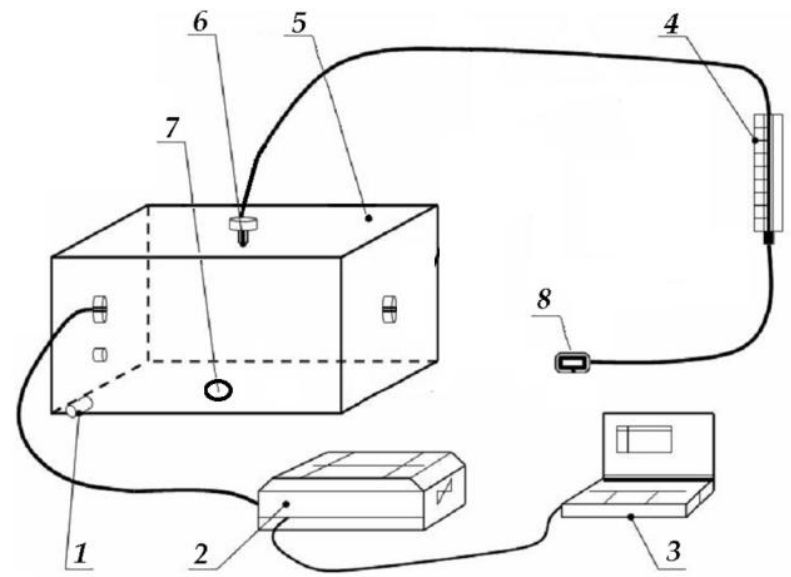

Fig. 2. Diagram of the research stand: 1 - draining valve, 2 - gas analyser, 3 - recorder, 4 - rotameter, 5 - measurement chamber, 6 - spray nozzle, 7 - Petri dish (for acetone and alcohols), 8 - water supply.

\section{Results and discussion}

Similar to ammonia, acetone and low molecular alcohols, changes in the concentration of methyl acetate in all of the tested cases were found to have an expotential drop in kinetic range $[17-19,21,28]$. The process may be described with the use of a differential equation similar to reaction of the pseudo first order in which the apparent constant absorption rate $k_{p}$ 
comprises the effectiveness of the water curtain, droplet distribution of droplets forming the absorption surface $S_{w}$ within a time unit, coefficient of jet geometry, and time of droplet falling through the gas cloud according to Equation (1):

$$
-\frac{d[A]}{d t}=-k_{p}[A]=-k_{G} S_{w} t_{f}[A]=-k G t_{f} S_{w}[A]
$$

in which

$[A]$ : concentration of vapours of the tested substance in the chamber [ppm]

$G$ : coefficient of jet geometry understood as a volume covered by the jet of the curtain in relation to the volume of the measurement chamber

$k$ : actual constant of the rate of absorption process $\left[\mathrm{m}^{-2} \mathrm{~s}^{-1}\right]$

$k_{p}$ : apparent constant of the rate of absorption process $\left[\mathrm{s}^{-1}\right]$ where: $\mathrm{k}_{\mathrm{p}}=\ln 2 / \mathrm{t}_{1 / 2}$

$k_{G}$ : geometric constant of the rate of absorption process $\left[\mathrm{m}^{-2} \mathrm{~s}^{-1}\right]$

$S_{w}$ : absorption surface generated in a time unit $\left[\mathrm{m}^{2} \mathrm{~s}^{-1}\right]$

$t_{f}$ : time of droplet passage through gas cloud [s]

$t_{1 / 2}$ : time of half-life concentration reduction [s]

Dependence curves for the concentration of methyl acetate vapours at a constant spraying rate of jet water $\left(\mathrm{q}=90 \mathrm{dm}^{3} / \mathrm{h}\right)$ and at constant temperature of $288 \mathrm{~K}$ were presented on fig. 3. As has already been mentioned, the ascertained change in concentration of methyl acetate within the kinetic scope had the nature of an expotential decay, which confirms the legitimacy of equation 1. To allow assessing the maximum rate of concentration reduction, a kinetic range was adopted with a span of $250 \mathrm{~s}$. An analysis of the kinetic scope was shown as insert on fig. 3 . The average value of $k_{p}$ with accuracy up to one standard deviation equalled to $\mathrm{k}_{\mathrm{p}}=(4.2+/-0.6) \times 10^{-3} \mathrm{~s}^{-1}$. (table 1 ). The determined variability index amounts to $15 \%$ and means an acceptable albeit a significant scatter in the recorded value of apparent constant absorption rate $\mathrm{k}_{\mathrm{p}}$. All the same the scatter value may be a result of using two systems to register the obtained data (PID, explosimeter). An analysis of data obtained earlier on in the same conditions for ammonia, acetone and low molecular aliphatic alcohols allows the presumption that the efficacy of water curtains to methyl acetate is approximately 13,57-fold lower than that for ammonia. It is also lower than for methanol (3.1) and acetone (1.5) [21]. 

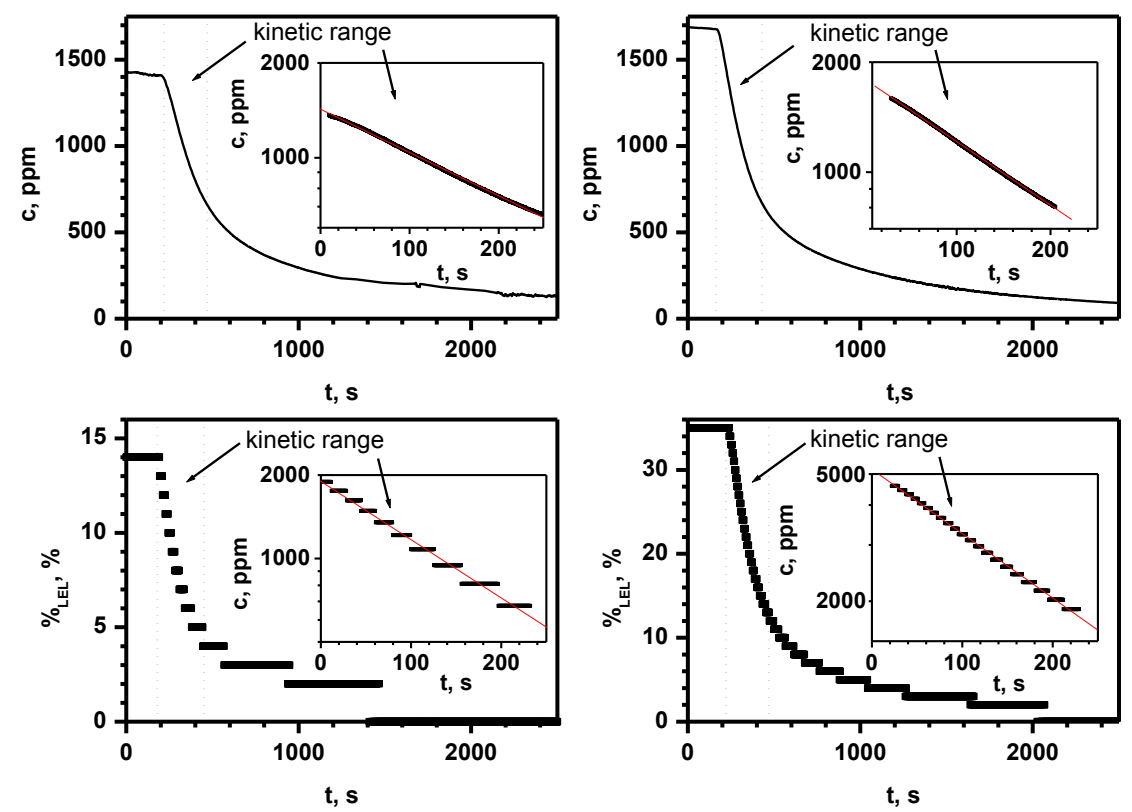

Fig. 3. Time dependence curves of methyl acetate concentration during provision of water curtain. Nozzle diameter $\Phi=1 \mathrm{~mm}$. Insert: $\ln (c)=\mathrm{f}(t)$ in kinetic range. Water flow efficiency $q=90 \mathrm{dm}^{3} \mathrm{~h}^{-1}$.

Its effectiveness is similar to the efficacy in relation to ethanol (table 1). On the other hand, water curtains were found to eliminate more effectively the vapours of AcOMe than of 1-propanol and 1-butanol. This is a very good effectiveness result taking into account a good albeit an incomplete miscibility of methyl acetate with water.

The efficacy of water curtains in relation to the analysed substances may be consequently ordered in the below sequence: $\mathrm{n}-\mathrm{BuOH}<\mathrm{n}-\mathrm{PrOH}<\mathrm{EtOH} \approx \mathrm{AcOMe}<$ $\mathrm{MeOH}<\mathrm{NH}_{3}$.

Table 1. Specification of kinetic data for selected substances: time of half-life concentration reduction $\left(t_{1 / 2}\right)$, apparent constant of the rate of absorption process $k_{p}$.

Data determined for spraying intensity $\mathrm{q}=90 \mathrm{dm}^{3} \mathrm{~h}^{-1}$.

\begin{tabular}{|c|c|c|c|c|}
\hline & $\mathbf{t}_{\mathbf{1} / \mathbf{2}}, \mathbf{s}$ & $\mathbf{k}_{\mathbf{p}}, \mathbf{s}^{-\mathbf{1}}$ & $\mathbf{k}_{\mathbf{p}(\mathbf{N H} 3)} / \mathbf{k}_{\mathbf{p}}$ & $\mathbf{k}_{\mathbf{p}} / \mathbf{k}_{\mathbf{p}(\mathbf{A c O M e})}$ \\
\hline Ammonia (NH $\left.\mathbf{N}_{\mathbf{3}}\right)$ & 12 & 0.0570 & 1.00 & 13.57 \\
\hline Acetone (Me $\mathbf{2} \mathbf{C O})$ & 111 & 0.0063 & 9.05 & 1.50 \\
\hline Methanol (Mech) & 53 & 0.0130 & 4.38 & 3.10 \\
\hline Ethanol (EtOH) & 166 & 0.0042 & 13.57 & 1.00 \\
\hline 1-propanol (n-PrOH) & 204 & 0.0034 & 16.76 & 0.81 \\
\hline 1-butanol (n-BuOH) & 303 & 0.0023 & 24.78 & 0.55 \\
\hline Methyl acetate (AcOMe) & 166 & 0.0042 & 13.57 & 1.00 \\
\hline
\end{tabular}




\section{Summary}

Results of the concluded tests of methyl acetate have clearly proven the legitimacy of applying water curtains to reduce the concentration of airborne vapours of this substance. The effectiveness of water curtains towards AcOMe was found to be nevertheless much lower than for ammonia $\mathbf{k}_{\mathbf{p}(\mathbf{N H} 3)} / \mathbf{k}_{\mathbf{p}}=13.57$. It is also lower than for methanol and acetone. The efficacy of water curtains in relation to methyl acetate was found to be similar to that of water curtains in relation to ethanol and higher than for 1-propanol and 1-butanol [21].

The obtained values of kinetic constants are high enough to prove that this does not undermine the legitimacy of applying water curtains in spatial elimination of AcOMe vapours in the event of its uncontrolled release also given additional effects such as diluting and reducing the vaporisation rate of its spillages or eliminating the hazard of electrostatic charges.

The research was carried out as part of the DOB-BIO6 / 06/11/2014 project "Mobile turbine rescue and firefighting system" financed by The National Centre for Research and Development in Poland (NCBiR).

\section{References}

1. Z. Salamonowicz, W. Jarosz, BiTP 353 (2012)

2. M. Polka, Z. Salamonowicz, M. Wolinski, B. Kukfisz, Procedia Eng. 45, 414 (2012)

3. C.J.H van den Bosch, R.A.P.M.Weterings, Methods for the Calculation of Physical Effects Third edition (Committee for the Prevention of Disasters, CPR 14E, TNO "Yellow Book", The Hague, 2005)

4. Z. Salamonowicz, M. Wolinski, M. Sobolewski, M. Polka, Przem. Chem. 93, 99 (2014)

5. A. S. Markowski, Zapobieganie stratom $w$ przemyśle. Cz. III Zarzadzanie bezpieczeństwem procesowym (Wydawnictwo Politechniki Łódzkiej, Łódź 2000)

6. W. Jarosz, Z. Salamonowicz, M. Majder-Lopatka, R. Matuszkiewicz, A. Dmochowska, Przem. Chem. 93, 686 (2014)

7. C.M.Pietersen, Analysis of the LPG Accident in San Juan Ixhuatepec, Mexico City, Report 85-0222 (TNO, Hague 1985)

8. Z. Salamonowicz, M. Kotowski, M. Polka, W. Barnat, Bull. Pol. Ac. Tech. 63, 289 (2015)

9. CCPS, Guidelines and Consequence Analysis of Chemical Releases (Center for Chemical Process Safety, American Institute of Chemical Engineers, New York 1999)

10. D. Wróblewski, T. Węsierski, Przem. Chem. 90, 2100 (2011)

11. X. Shen, J. Zhang, M. Hua, X. Pan, Proc. Saf. Env. Prot. 105, 250 (2017)

12. M. Hua, X. Shen, J. Zhang, X. Pan, Proc. Saf. Env. Prot. 116, 737 (2018)

13. A. Dandrieux, G. Dusserre, J. Ollivier, H. Fournet, J. Loss Prev. Ind. 14, 349 (2001)

14. O. Isnard, L. Soulhac, G. Dusserre, J. Loss Prev. Ind. 12, 471 (1999)

15. M. Hua, M. Qi, T. Yue, X. Pi, X. Pan, J.C. Jiang, Procedia Eng. 211, 256 (2018)

16. C. Cheng, W. Tan, H. Du, L. Liu, J. Loss Prev. Ind. 36, 120 (2015)

17. T. Węsierski, M. Majder-Łopatka, R. Matuszkiewicz, R. Porowski, Przem. Chem. 91, 1424 (2012)

18. T. Węsierski, Przem. Chem. 94, 728 (2015) 
19. T. Węsierski, Przem. Chem. 96, 1539 (2017)

20. V.M. Fthenakis, D.N. Blewitt, J. Loss Prev. Ind., 6, 209 (1993)

21. T. Węsierski, M. Majder-Łopatka, Appl. Sci. 8, 1971 (2018)

22. A. Dandrieux, G. Dusserre, J. Ollivier, J. Loss Prev. Ind., 15, 5 (2002)

23. M.A Rana, M.S. Mannan, J. Loss Prev. Ind., 23, 768 (2010)

24. M.A. Rana, B.R. Cormier, J.A. Suardin, Y. Zhang, M.S. Mannan, M.S. Proc. Saf. Progress 27, 345 (2008)

25. M.A. Rana, M.S. Mannan, Water Curtain Application for Forced Dispersion of LNG Vapor. In Proceedings of the O'Connor 9th Topical Conference on Natural Gas Utilization (AIChE Spring National Meeting, Tampa, FL, USA, 26-30 April 2009)

26. M.A. Rana, Y. Guo, M.S. Mannan, J. Loss Prev. Ind. 23, 77 (2010)

27. M. Qi, T. Yue, M. Hua, X. Pan, J. Jiang, J. Loss Prev. Ind. 43, 471 (2016)

28. S. Twomey, Atmospheric Aerosols (Elsevier Scientific Publishing Company, Amsterdam, 1977) 